\title{
USING FARM RESIDUALS IN PRODUCING GYPSUM BOARDS
}

\author{
E. A. El Saeidy*
}

\section{ABSTRACT}

Disposal of farm residuals specially cotton and maize stalks and rice straw is still one of the main problems facing Egyptian farmers. The definition of the amount of these residuals is not clear. Each of the Ministry of Agriculture and the Ministry of Environment estimated it from its point of view. Anyhow, the amount of these residualis at least 35 Miolton per year. It represents a big problem for the farmers and negatively affect the surrounding environment where they are disposed of primitive ways by burning illegal. This process is harmful not only for the environment but also for the Human.

Storage also is a dangerous process because of the fire danger. In the other hand, it is a good habitat for plant pathogens and vectors. The good thinking is to improve the economic situation of these residuals. Some experts were done for the disposal of it in the form of fuel briquettes bio eco-friendly high economic return operations.

\section{INTRODUCTION}

The Ministry of Agriculture and Land Reclamation (2013)Stated in its annual statistical year book that the agricultural wastes in Egypt reached about 30 million tons per year. That was confirmed by GIZ (2014) in its report for "Solid Waste Management in Egypt, 2013", and also by NSWMP(2014).

Only 7 million tons of these residuals are being utilized as animal feed and 4

\section{Ass. Prof. Agric. Eng., Fac. Agric., Mynofia uni.}

million as organic manure. These crop residues result are produced from harvesting agricultural crops in the form of leaves, stem and shelves which are characterized as coarse plant by products and big size, chemically low in protein and fat content. it is also high in lignin and cellulous contents Shaban and Sawan(2010).

\section{*Lecturer. of Ag. Eng. Dept., Faculty of Ag. Menofia. University}


Farmers get rid of a huge amount of these residuals by burning it illegally in the field. Burning residuals causes air pollution, soil erosion, and a decrease in biological activities, which eventually leads to lower yields. Burning residuals releases smoke and other pollutants which adversely affect air quality, visibility, and human and environmental health. The low Sulphur content of crop residues as compared to fossil fuels and their use as fuel does not add to the $\mathrm{CO} 2$ content of the atmosphere (Gamea, et al. 2007).

burning of farm wastes specially rice straw or cotton stalks is the main reason for the black cloud that appears in Egypt every year from the beginning of October and continues until the end of November.

The incomplete burning of these wastes - where burn this waste which is still high humidity up to $50 \%$ - lead to the emission of carbon dioxide as well as a large proportion of carbon monoxide and the latter also is a very serious for health and toxic if inhaled (El Saeidy 2004).

Mostafa, et al (2011) revealed that, In Egypt burning of rice straw releases large amounts of air pollutants causing serious environmental problems

Egypt is the largest rice producer in the Near East region, where rice cultivation area occupies over 1,093,303 feddan. The average yield of rice straw reaches about with 2.3 million tons/year. Rice straw represent about $6.6 \%$ of the total amount of agricultural residues. These are materials comprising mainly rice straw, which present a disposal problem. The area of rice crop cultivation accounts for about $13 \%$ of the cultivated area in Egypt (MALR, 2013).

Guozhong et al (2002) mentioned that, Gypsum board is the generic name for a family of panel products that composed primarily of gypsum, and a paper surfacing on the face, back and long edges. Gypsum board is one of several building materials covered by the umbrella term "gypsum panel products." All gypsum panel products contain gypsum cores; however, they can be faced with a variety of different materials, including paper and fiberglass mats.

Gypsum-base composites are receiving more and more extensive application in the development of new-type wall body materials. A lot of companies in other countries have put out new-type building materials that compound gypsum with wood shaving, and have successfully 
developed several kinds of production equipment. This kind of products have the following merits.

1- Low density $\left(100-1200 \mathrm{~kg} / \mathrm{m}^{3}\right)$.

2- Good properties of insulation against heat and sound.

3- High strength/density make it fit to be used as light partition wall.

4- Cheap price and wise source make the production costs very low.

The researches on substituting crop fiber for wooden shaving as strengthening material have very important practical meanings.

Keerthan, $P$ and M. Mahendran (2012). Said that gypsum plasterboard consists of gypsum core sandwiched between two layers of paper. The paper provides adequate tensile strength for handling and usage. It contains also other materials in small quantities such as glass fibers to improve their durability. It is commonly used as a fire safety material in the building industry around the world. This is due to the ease of fabrication and workmanship. The widespread availability of the primary material for its production.

Tayel et al. (2010) stated that straw was first used to reinforce mud against cracking. a lattice of straw of straw cress- crossing a layer of mud producing a surface that remained crack free for decades or centuries.

Allam et al. (2011) reported that one of the most abandoned materials in Egypt is rice straw. Instead of burning. Recycling it with mixture of cement forms a sustainable low cost building material, which also reduces the atmospheric pollution. In addition to their benefits, the resulting composite rice straw bricks could act as a thermal insulator that can be used in building for severe weather. The use of thermal insulation helps reduce energy costs and improving indoor temperature.

Beall (2000) stated that, rice straw is characterized by lower amounts of cellulose and lignin added to lower amount of cellulose and much lower amount of lignin. He mentioned that the cell wall makeup of rice straw may be quite different than that of softwood.Ash content is very high relative to wood and this is primarily made up of silica, $75-80 \%$.

Gad et al., 1987 said that The general shape of cotton stalks ranges from columnar through pyramidal to rounded. The shape is determined by the length of the branches. The stems have a moderately thick, tough bark in which best fibres are prominent. The outer layer of the bark is quite corky. It is of a yellowish-brown colour on the older parts of the stems 
and greenish to reddish on the younger. The larger side of stems consists of well-developed wood structure with prominent wood rays and water carrying vessels.

Friday, M. and Cramer, S. (2002).Noise can interfere with sleep, rest and conversation and cause fatigue, irritability, headaches and stress. We all need to contain and reduce noise in order to enjoy a healthy life. Thoughtful design and practice can reduce the impact of noise on our lives and improve the quality of our living environment.

Hyder (1993) mentioned that the decibel system (dB) is mostly used to compare between the different sound levels sound. It is the Unit of Sound Intensity Level. He mentioned also that rice straw pressed under high temperature and covered with craft paper from both sides and formed as boards. It Isolate about 40dB.

EEAA (1994) Stated inExecutive Regulation of law No. (4) for year 1994for Environment Protection. (Appendix 8).The maximum permissible limit for noise intensity in the different areas as presented in Table (1)

Table (1) The maximum permissible limit for noise intensity in the different areas:

\begin{tabular}{|l|c|c|c|c|c|c|}
\hline \multirow{2}{*}{\multicolumn{1}{|c|}{ TYPE OF AREA }} & \multicolumn{5}{|c|}{$\begin{array}{c}\text { PERMISSIBLE LIMIT FOR NOISE } \\
\text { INTENSITY DECIBEL (a) }\end{array}$} \\
\cline { 2 - 7 } & From & To & From & To & From & To \\
\cline { 2 - 7 } & 55 & 65 & 50 & 60 & 45 & 55 \\
\hline $\begin{array}{l}\text { Commercial, administrative } \\
\text { and downtown areas }\end{array}$ & 50 & 60 & 45 & 55 & 40 & 50 \\
\hline $\begin{array}{l}\text { Residential areas in which } \\
\text { can be found some } \\
\text { workshops or commercial } \\
\text { establishments or which are } \\
\text { located on a main road }\end{array}$ & 45 & 55 & 40 & 50 & 35 & 45 \\
\hline Residential areas in the city & 40 & 50 & 35 & 45 & 30 & 40 \\
\hline $\begin{array}{l}\text { Residential suburbs with } \\
\text { low traffic }\end{array}$ & 35 & 45 & 30 & 40 & 25 & 35 \\
\hline $\begin{array}{l}\text { Residential rural areas, } \\
\text { hospitals and gardens }\end{array}$ & 60 & 70 & 55 & 65 & 50 & 60 \\
\hline $\begin{array}{l}\text { Industrial areas (heavy } \\
\text { industries) }\end{array}$ & & & & & & \\
\hline
\end{tabular}


Day from 7 a.m. to 6 p.m.

Evening from 6 p.m. to 10 p.m.

Night from 10 p.m. to 7 a.m.

The aim of this research is to use these agricultural residuesin the production ofgypsum boardsandknow howisolatedsound.

This aim could be achieved by studying the following objectives:

1. Chop a number of residues in shredding machines.

2. Make the gypsum boards with farm residues.

3. Study the properties and the efficiency of these boards.

\section{MATERIALS AND METHODS}

\section{Gypsum Boards:}

To produce gypsum board as shown in Fig. (1) and (2) gypsum is mixed with water and additivesto form a slurry. This mixture is fed into a wooden form of inner dimension $70 \times 70 \times 1 \mathrm{~cm}$. Before feeding the slurry, the form was covered buy a polyethylene sheet to prevent it to stick it with the wooden form.

The gypsum was mixed with the farm residuals as follow:

1- Gypsum and rice straw in a ratio of $1: 1$

2- Gypsum and cotton stalks in a ratio of $1: 1$

3- Gypsum and rice straw in a ratio of 1:0.5

4- Gypsum and cotton stalks in a ratio of 1:0.5

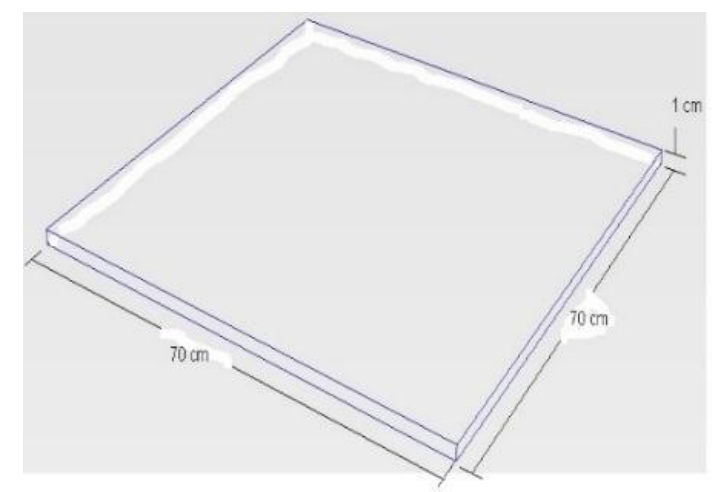

Fig. (1)The Gypsum board dimension 


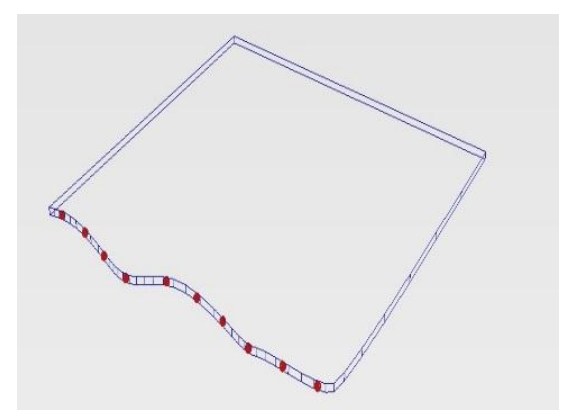

Fig. (2) Cross section in the Gypsum board

\section{Sound Level Meter Fig. 2:}

Model: Quest Models2200 provides Precision Class/Type 2 accuracy.

Measurement range: $30-140 \mathrm{~dB}$.

Company: Quest Technologies, 1060 Corporate Center Drive.Wisconsin 53066 USA.

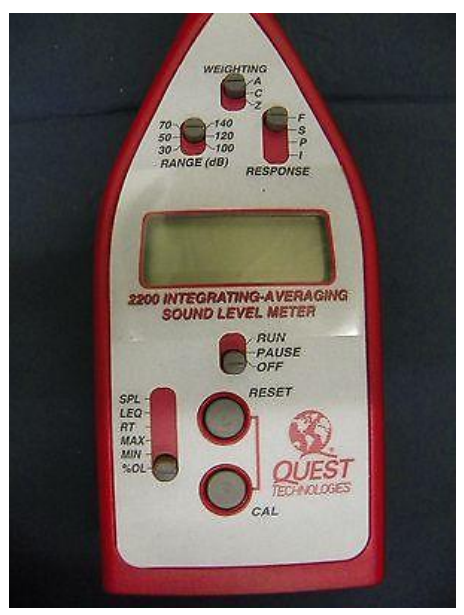

Fig. 1 Quest Sound Level Meter

\section{Sound source:}

A sound source with fixed and continous ring tone was used in this work. It was fixed in a sound level of $79 \mathrm{~dB}$.

\section{Residules Chopping:}

The Rice straw and cotton stalks used in this work was chopped in a chopper machine. The average length of the chopped rice straw was about $20 \mathrm{~mm}$ and for cotton stalks was $17 \mathrm{~mm}$. the chopper machine is locally manufactred. It works with the tractor P.T.O. Fig. 3. 


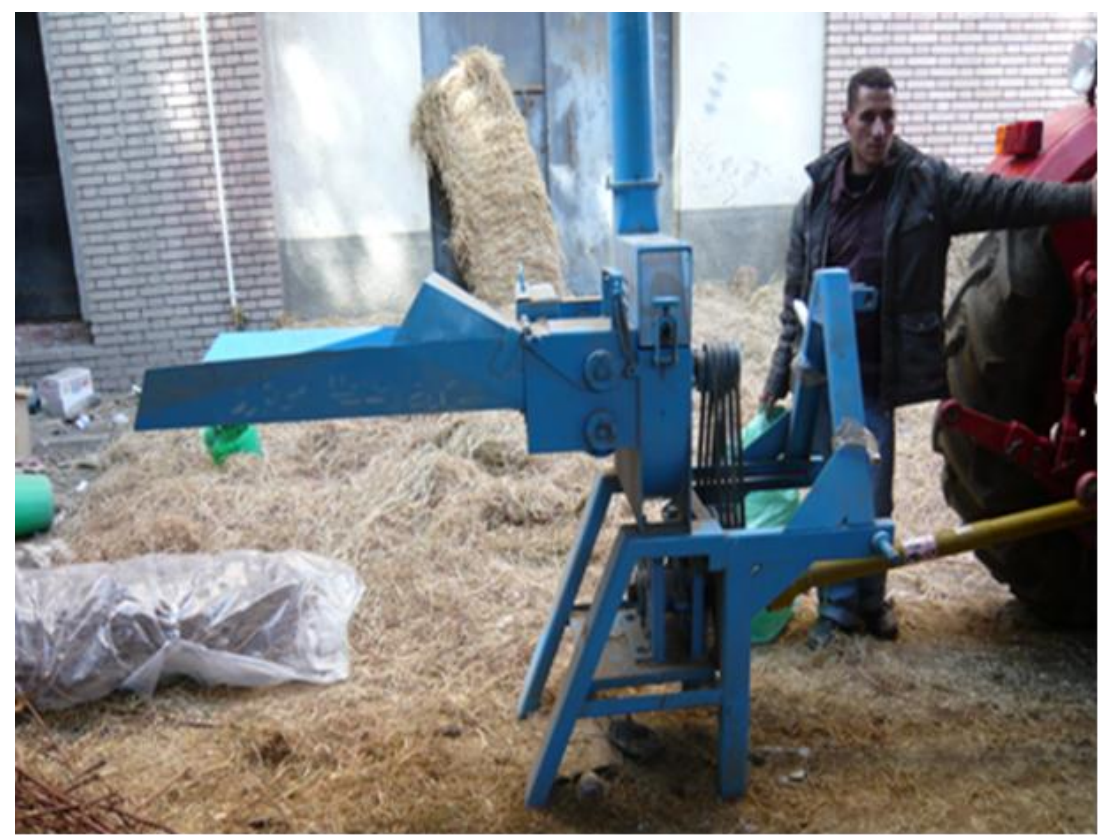

Fig. (3). The chopper machine.

It has the following Specifications:

1- The Cutting-head of a diameter $54 \mathrm{~cm}$ has two radial knives which are fixed on it by four bolts.

2- Feeding drum dimension are $37 \mathrm{~cm}$ length, $14 \mathrm{~cm}$ diameter and $5.5 \mathrm{~cm}$ height. It used to push the plant stems to the cutter-head for cutting

3- The power was transmitted to the cutter-head and feeding drum from the tractor P.T.O by a universal joint. Two pulleys (driver and driven) transport the power to the cutter-head through four "V" belts.

\section{The Prototype Room.}

A wooden frame was manufactures as a prototype room. It consists of four wooden columns'. It has a square cross section of demotions $10 \mathrm{x} 10$ $\mathrm{cm}$. the bottom is closed by a plywood panel. The sides are open construct the gypsum borders and remove it. For this reason, each two opposite sides of the column have a grooved channel. the wooden panel which cover the prototype has a square hole of dimensions 15 x 15 and 
covered with two layer from glass to see the sound meter level. The sound meter level put in the middle if the room and on a height of $35 \mathrm{~cm}$.

\section{The Commercial Gypsum Board.}

A commercial gypsum board was cut to same dimensions of the manufactured one to make a comparison between them.

\section{Sound Measuring Method.}

The experiment was done in a close empty room. No air streams were found The processed gypsum board were constructed in the wooden frame. The Sound Level Meter put inside the box and the it was covered by the play wood with the glass window. The sound source is operated and the results recorded.

The experiment was done once when the boards was uncovered and another time covered with craft paper.

\section{RESULTS AND DESICCATIONS}

\section{The effect of residual kind on the insulation performance.}

\section{A-Gypsum / material ratio of 1: 0.5}

The data presented in Figure (1) shows that straw boards give the best results in isolation than the cotton boards. Bothe of them was better in results than the commercial gypsum board.

On the other hand, covering the all the boards with craft paper have a remarkable effect in insulation process for all the boards.

For rice straw the covering process increased the insulation with about $4 \%$ than uncovering.

The uncovers straw boards isolated the noise in a ratio of $\% 9$. As for the uncovers straw boards isolated the noise in a ratio of $13.3 \%$

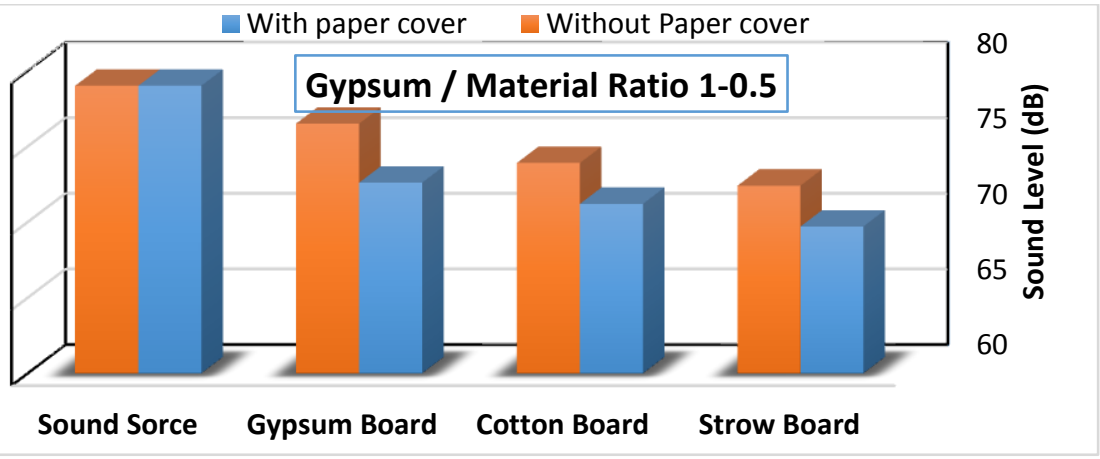

Fig (1) The effect of residual kind on the insulation performancefor Gypsum / material ratio of 1: 0.5 


\section{B-Gypsum / material 1: 1}

The data presented in Figure (2) shows that straw boards give also the best results in isolation than the cotton boards. Bothe of them was better in results than the commercial gypsum board.

On the other hand, covering the all the boards with craft paper have a remarkable effect in insulation process for all the boards.

For rice straw the covering process increased the insulation with about $3.7 \%$ than uncovering.

The uncovers straw boards isolated the noise in a ratio of $\%$ 17.7. As for the covers straw boards isolated the noise in a ratio of $22.1 \%$

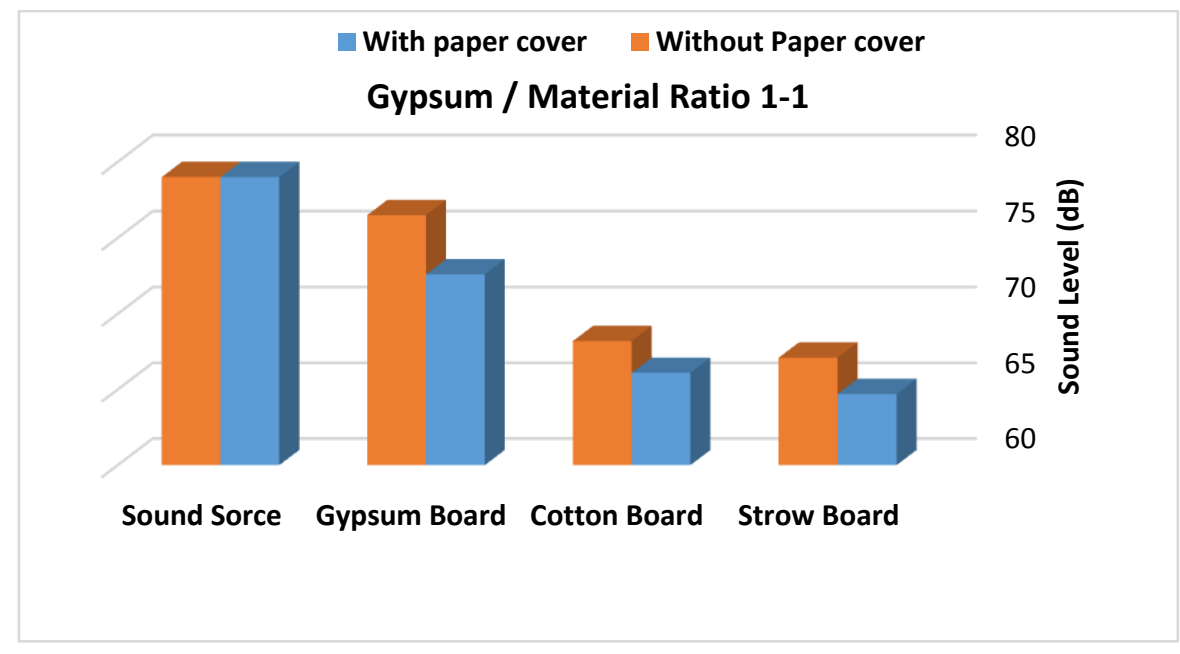

Fig (2) The effect of residual kind on the insulation performancefor Gypsum / material ratio of 1: 1

\section{The effect of mixing ratio on the insulation performance.}

\section{A- Rice Straw}

The data presented in Figure (3) shows that mixing ratio 1:1 for straw boards give also the best results in isolation than the mixing ratio of 1:0.5. Bothe of them was better in results than the commercial gypsum board. On the other hand, covering the all the boards with craft paper have a remarkable effect in insulation process for all the boards.

For rice straw the covering process increased the insulation for mixing ratio $1: 1$ with about $7.7 \%$ than the mixing ratio of $1: 0.5$. 


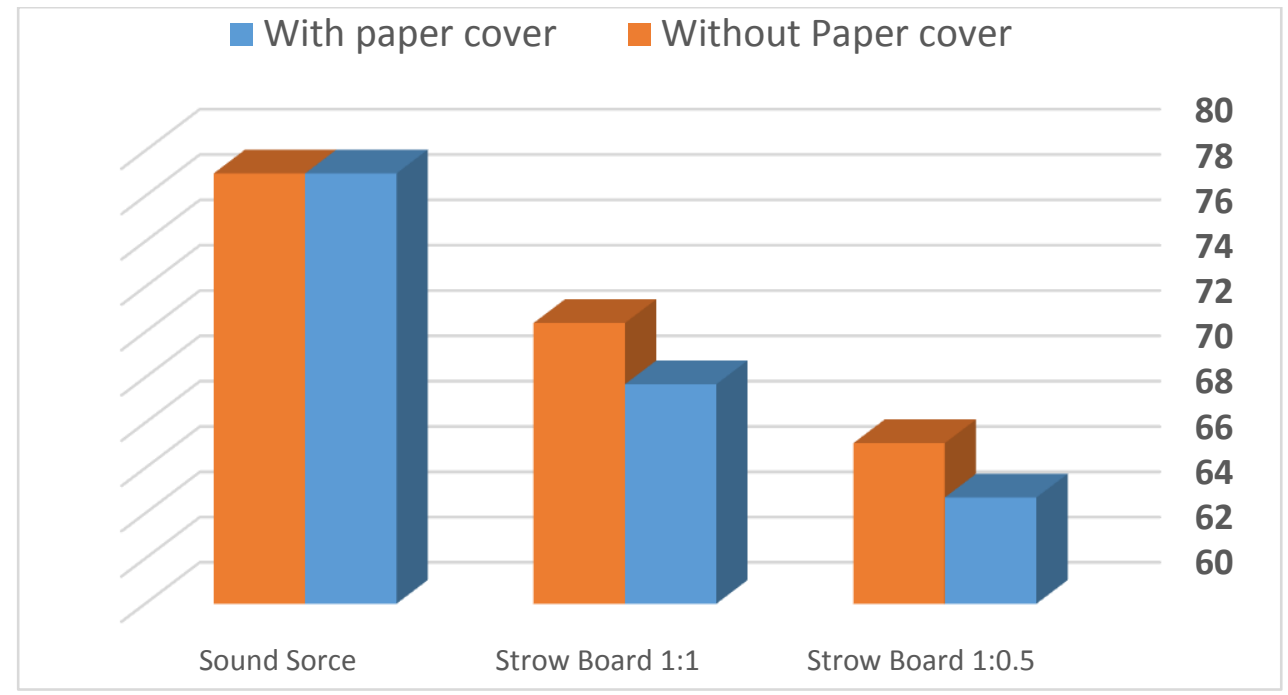

Fig (3) The effect of mixing ratio on the insulation performancefor Straw

The effect of mixing ratio on the insulation performance.

\section{A- Cotton Stalks}

The data presented in Figure (4) shows that mixing ratio 1:1 for cotton stalks boards give also the best results in isolation than the mixing ratio of 1:0.5. Bothe of them was better in results than the commercial gypsum board.

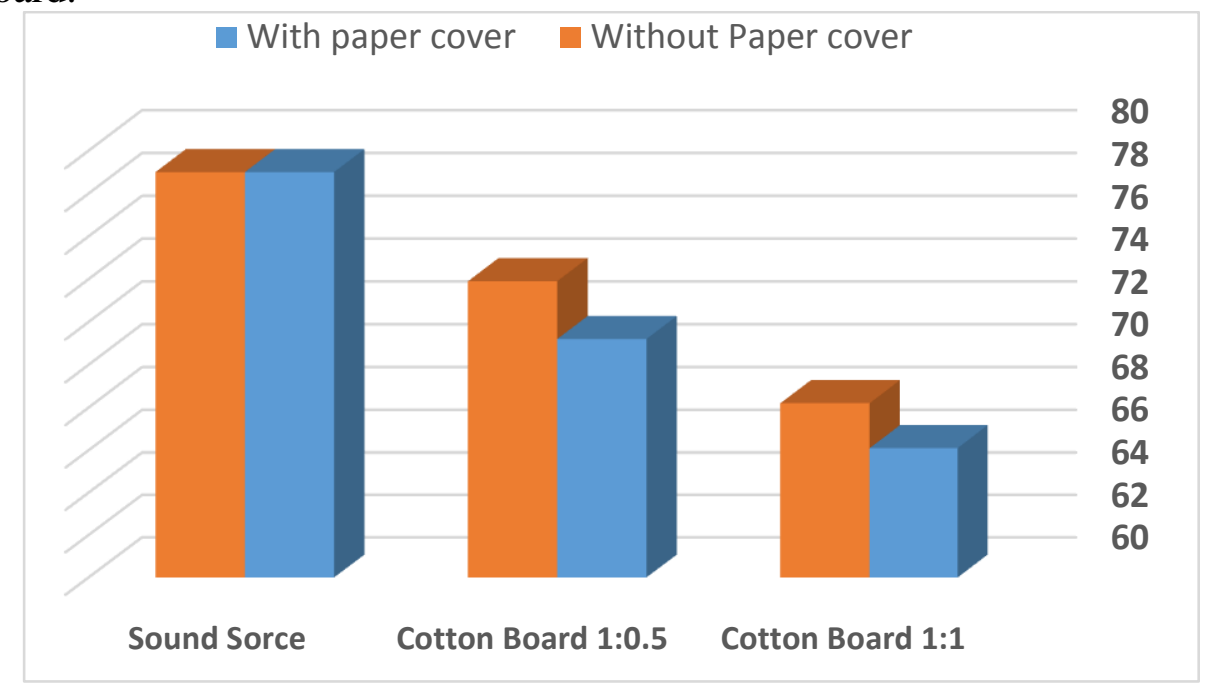

Fig (4) The effect of mixing ratio on the insulation performancefor Cotton Stalks 
For rice straw the covering process increased the insulation for mixing ratio $1: 1$ with about $7.7 \%$ also than the mixing ratio of $1: 0.5$. It indicates that the mixing ratio has a remarkable effect on the insulation performance of the boards.

Covering the boards with the craft paper has also a remarkable effect on the insulation performance of the boards regardless the mixing ratio was.

\section{CONCLUSION}

The Problem of farm residuals disposal still a problem in Egypt. It reaches about 30 Mio. Ton per year. This work is an attempt to help recycle the agricultural by using it in producing gypsum boards. The obtained results can be summarized as follows:

- For the mixing ratio of 1:0.5, uncovered straw boards isolated the noise at a ratio of $9 \%$ while covered straw boards isolated the noise at a ratio of $13.3 \%$

- For the mixing ratio of 1:1, uncovered straw boards isolated the noise at a ratio of $\% 17.7$. while covered straw boards isolated the noise at a ratio of $22.1 \%$.

- Covering all boards with craft paper has a remarkable effect on insulation process for all the boards investigated regardless the mixing ratio was.

- The mixing ratio 1:1 for straw boards produced the best results in isolation process than the mixing ratio of 1:0.5. Both of them were better in results than the commercial gypsum boards.

This work should to be continued to study the properties of these boards.

\section{REFERENCES}

Allam, M. G. Garas and H. El Kady (2011.) Recycled chops rice Straw - Cement Bricks: Mechanical, Fire Resestance and economical Assessment. Australian Journal of Basics and Applied Scenice, 5(2): 27-33, 2011.

Beall, F. C. (2000)."Physical Properties of Wood".Unpublished Class Notes. Forest Products Laboratory, University of California. ESPM 286. 
EEAA (1994).Egyptian Environmental Affairs Agency.Executive Regulation

of law No. (4)for year1994for Environment Protection. (Appendix 8). The Public Authority for the Official Press, Cairo, Egypt.

El Saeidy (2004). The technological fundamentals of briquetting cotton stalks as a Biofuel, Ph.D. thesis, Humboldt University of Berlin.

Friday, M. and Cramer, S.(2002).Toward Engineering Design of Gypsum Board Fire Barriers. Advances in building technologies. Volume 1, 105 - 112. Elsevier

Gad, A., Omar, M., Kasem, A. and Karim, U. 1987. The Morphology of the crops and grasses. The Modern Publications. Alexandria, Egypt.

Gamea G. R., E. A. El Saeidy and S. F. El Sisi (2012)."Quality properties for cotton stalks and rice straw briquettes". The 19 Annual Conference of Misr Journal of Agricultural Engineering, 14-15 November, 2015, Egypt.

GIZ (Deutsche GesellschaftFuer International Suzammenarbeit, GmbH) (2014) "Country report on the solid waste management in Egypt". The regional solid waste exchange of information and expertise network in Mashreq and Maghreb countries. Info gate. Internet: http://www.sweep-net.org/.

Guozhong, I. ; Y. Yanzhen. ; L. Jianquan. ;andL.Changchun. "Properties study of cotton stalk fiber/ gypsum composite ". Cement and Concrete Research 33 (2003) 43-46

.Hyder, F. A.(1993). Modern Encyclopedia in Building Construction Technology, third edition. Monshat El Maref, Alexandria. Egypt.

Keerthan, P and M. Mahendran (2012). Numerical study of gypsum plasterboard panels under standard fire conditions. Fire Safety Journal. 53 (2012) 105-119.Elsevier. 
MALR, (2013)."Ministry of Agriculture and Land Reclamation"Economic Affairs Sector, Statistical Yearbook, Egypt.

Mostafa, E. A.; G. L. Garas.; and H. G. El Kady(2011)"Recycled Chopped Rice Straw - Cement Bricks: Mechanical, Fire Resistance and Economical Assessment". Australian Journal of Basic and Applied Sciences, 5(2): 27-33.

NSWMP. (2014). National Solid Waste Management Program. The Second Egyptian Solid Waste Management Forum 24-25 November 2014- Cairo -Egypt.

Shaban, D. A.; and O. M. Sawan (2010)"The Utilization of Agricultural Waste as One of the Environmental Issues in Egypt (A Case Study)". Journal of Applied Sciences Research, 6(8): 1116-1124.

Tayel, S. A. ; M. F. A. Khairy. ; I. S. El-Soaly. ;and A. M. Moussa (2010). "Using adhesive matter for agricultural wastes as building bricks". Misr J. Ag. Eng., 27(1): 347-361.

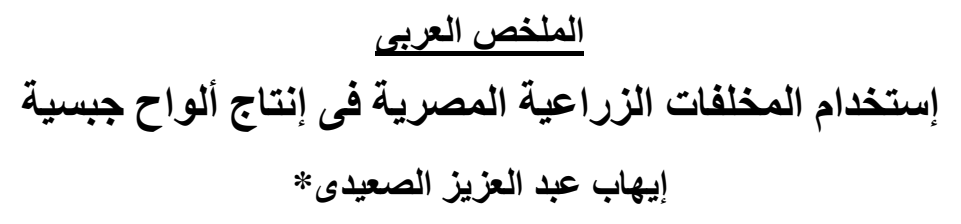

التخلص من المخلفات الزراعية المصرية خصوصا حطب القطن وقش الأرز وحطب الذرة

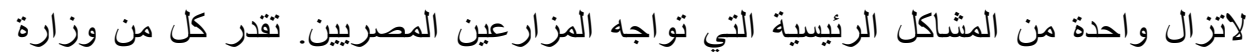

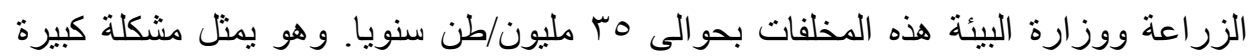

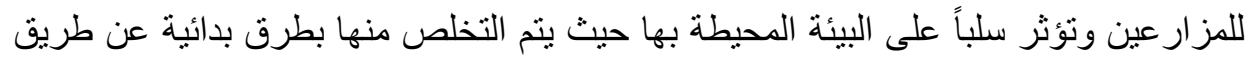
الحرق الغير قانوني. هذه العملية ضارة ليس فقط على البيئة ولكن أيضا من أجل الإنسان.

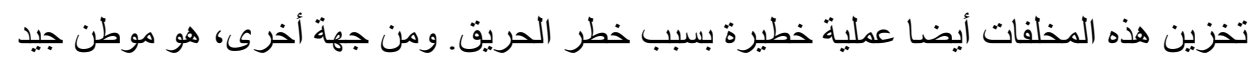

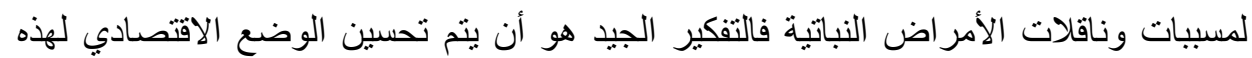

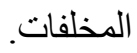

*مدرس الهندسة الزراعية ـ كلية الزراعة - جامعة المنوفية 
الهدف من هذا البحث هو استخدام هذه المخلفات الزر اعية في إنتاج ألو اح جبسية مدر اسة كفائتها فى عزل الصوت وقد أثنتت النتائج ما يلى هذه: الفئ

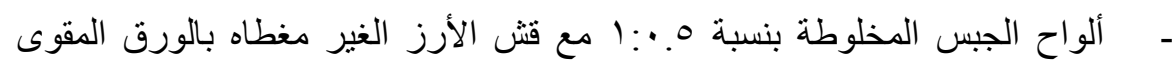

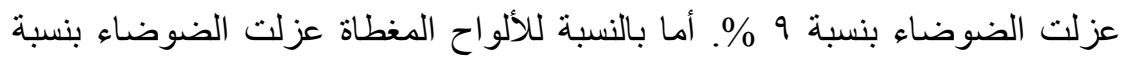
\%

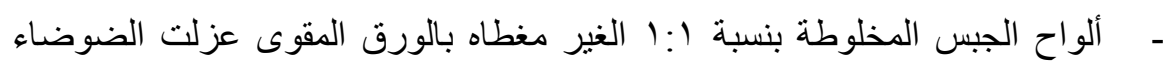

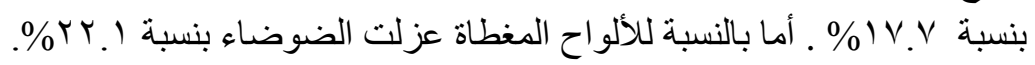

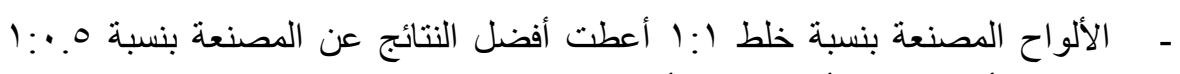
وكلاهما أعطى نتائج أفضل من الألو اح الجبسية التجارية.

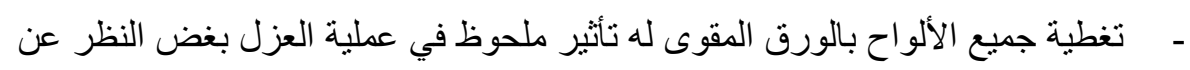
نسبة الخلط. 